\title{
A Comprehensive Approach: Inclusive, Smart and Green Urban Development
}

\author{
Podejście zespolone: włączający, inteligentny \\ i ekologiczny rozwój miast
}

\section{Justyna Przywojska*, Aldona Podgórniak-Krzykacz ${ }^{\star \star}$}

\author{
Department of Labour and Social Policy, University of Łódź; ul. Rewolucji 1905 r. nr 37, \\ 90-214 Łódź, Poland \\ E-mails: *justyna.przywojska@uni.lodz.pl, **aldona.podgorniak@uni.lodz.pl
}

\begin{abstract}
The subject literature provides knowledge about various contemporary concepts of urban development, emphasizing a variety of goals and priorities of this process. Although sustainability should be a key objective of development policy, the methods of achieving it seem to be diverse. As a result, there are many theories describing development processes on a local scale, but there are no scientific attempts to summarise them or to comprehensively evaluate them. In the presented article such an attempt was initiated - the evolution of the concept of sustainable development in the context of transformation of the role of man in socio-economic and political processes from homo-oeconomicus to homo cooperativus was outlined and the assumptions of contemporary concepts of urban development (smart city, eco city and compact city) were identified and evaluated in terms of their cohesion and implementation of sustainable development principles. On this basis, a conceptual framework for an inclusive urban development model was defined, considering their key values in a synergic way.
\end{abstract}

Key words: urban development, sustainability, smart city, eco city, compact city, social inclusion

\section{Streszczenie}

Literatura przedmiotu dostarcza wiedzy na temat coraz to nowszych koncepcji rozwoju miast, akcentujących różnorodne cele i priorytety tego procesu. Pomimo, iż kluczowym celem prowadzenia polityki rozwoju powinna być trwałość, postulowane metody jej osiągania wydają się być zróżnicowane. W efekcie równolegle funkcjonuje wiele teorii opisujących procesy rozwoju w skali lokalnej, przy czym brakuje naukowych prób ich podsumowania, czy kompleksowej oceny. W prezentowanym artykule podjęto taką próbę - zarysowano ewolucję koncepcji rozwoju zrównoważonego w kontekście transformacji roli człowieka w procesach społeczno-gospodarczych i politycznych od homo-oeconomicus do homo cooperativus oraz zidentyfikowano i poddano ocenie założenia współczesnych koncepcji rozwoju miast (smart city, eco city i compact city), pod kątem ich spójności i realizacji zasad rozwoju zrównoważonego. Na tej podstawie określone zostały ramy koncepcyjne dla modelu inkluzywnego rozwoju miast, uwzględniającego w sposób synergiczny ich kluczowe wartości.

Słowa kluczowe: rozwój miast, zrównoważoność, miasto inteligentne, miasto ekologiczne, miasto kompaktowe, inkluzja społeczna

\section{Introduction}

As a concept emphasising the relationship between the condition of the environment and exploitation of the resources as well as between economy and social inclusion, sustainable development inscribed itself into the mainstream territorial development pro- cesses in the 1990s (Deslatte and Stokan, 2017; Lin and Shih, 2018; Rydzewski, 2019). The concept evolved since then (Papuziński, 2018) and was further implemented at a local level. Portney (2013) notices that an increasing number of cities employ development strategies that aim to preserve or improve environmental values and quality of life, reduce en- 
ergy consumption or carbon dioxide emissions. At the same time, cities' authorities have to face ever newer challenges which require the design and implementation of the proper urban policy - technological revolution, ageing population or intensified migration movements can serve as an example here. The main purpose of our work is to identify and assess the assumptions of the contemporary urban development concepts in terms of their cohesion and implementation of sustainable development principles. Therefore, we attempt to define a conceptual framework for the urban development model which includes their key values synergistically. The article is of purely theoretical nature - it comprises a review of contemporary literature on the subject. The analysis involved SCOPUS database resources subscribed by the Library of University of Łódź. The following criteria were used: date range: 2010-2018; subject areas: social sciences; language: English; document type: article; keywords: urban and sustainable and development, urban area.

Although the literature review indicates that there are numerous new urban development concepts, e.g. resilient city (Newman, Beatley, Boyer, 2009), sharing city (Agyeman, McLaren, Borrego, 2013), global city (Sassen, 2005), our study pays particular attention to the three concepts selected - smart city, eco city and compact city. Not only are they the most popular, but also they fit the most into the assumptions and objectives of sustainable development.

\section{Evolution of the sustainable development concept}

The end of 1980s can be marked as the beginning of an increased interest in sustainable development. The report by the World Commission on Environment and Development announced in 1987 which defines sustainable development as a process that responds to the needs of the present generation without diminishing the opportunities of future generation to meet their needs, made a significant contribution to this process. Another crucial and broad definition of this term was provided at the Earth Summit in Rio de Janeiro in 1992. Sustainable development was defined there as a strategy that encompasses environmental, social, technical and technological as well as organisational transformations that aim to achieve rational and sustainable prosperity which can be passed on to next generations without the fear of the destruction of natural resources and ecosystems. Since then, both the sustainable development concept and the approach to its practical application have evolved. Borys and Czaja (2009), as well as Wołczek (2014) who builds on their achievements, presented an interesting attempt to classify these changes. To them, sustainable development concept evolved in five stages:

1. Inspiration - emergence of the idea and attempts to identify it at the turn of the 1960s and 1970s.
2. Maturation - intensive work on giving substance to the sustainable development concept, resulting in the preparation of Our Common Future report in 1987.

3. Fascination - characterised by a rapid and massive increase of interest in the concept in the period preceding the Earth Summit in Rio de Janeiro in 1992.

4. Implementation - actions undertaken to disseminate the application dimension which resulted in numerous projects of its implementation into socio-economic practice on a macro and micro scale. At an organisational level, issues such as corporate social responsibility and ethics gained importance here.

5. Doubts - adoption of the Millennium Development Goals (2000) and the years following it, characterised by numerous doubts about the feasibility of implementing this idea in practice.

In turn, based on the approach presented above, Wołczek indicates the existence of the $6^{\text {th }}$ stage of evolution which has its roots in the second decade of $21^{\text {st }}$ century and he calls it expectancy. To him, it can be described as the anticipation of the effects of all the steps undertaken so far within the sustainable development framework. Though he notices an increased interest in the green economy discussed during the Rio de Janeiro summit in 2012, he does not perceive this phenomenon as another breakthrough. We do not fully agree with Wołczek's ideas, especially since he suggested that this expectancy stage is characterised by passivity. Meanwhile, the $21^{\text {st }}$ century can be described in terms of exceptional dynamics of economic processes and significant consumerism which gradually contrasted with the scientific movement of the reduction of consumption, circularity, balance, sustainability and social inclusion as the axiological basis of social, economic and political change. Contemporary sustainability challenges are reflected in the UN agendas, e.g. Transforming our world: the 2030 Agenda for Sustainable Development (2015), the New Urban Agenda (2016). Therefore, we would like to exchange expectancy stage with recalibration, i.e. the time of adapting methods and tools of sustainable development to a dynamically changing environment. Based on the review of the achievements of renowned scientists and publicists, we believe that now there is a time of an increased interest in reducing inequalities, cooperation, inclusion and social solidarity as part of sustainable development and with the simultaneous dynamic development of information and communication technologies (Bauman, Bauman, Kociatkiewicz, Kostera, 2017; Stiglitz, 2015; Bornstein, 2015; Therborn, 2013; Piketty, 2015). This is well reflected by Mączyńska (2011) who points to a useful utopia of the anthropological breakthrough of modernity which makes people feel more and more threatened, more and more overwhelmed by this dominance of current events over strategically deepened reflec- 
tion. Change of behaviour as well as the reflection on unnecessary elements of material civilization should mirror this utopian breakthrough. Thus, it ought to signify the disturbance of a civilization built around the buy, buy, buy, throw, throw, throw, indebt yourself, indebt yourself principle, where the wealth of the world does not really turn into a sufficient quality of life.

The expansion of post-growth ideas (Büchsa and Koch, 2019; Heikkurinen et al., 2019; Vandeverter et al., 2019), renaissance of interest in common goods (Perkins, 2019, Sokołowicz, 2017) and formulating the principles of a shared economy model, including cities as places of exchange (Agyeman et al., 2013, Harmaala, 2015) - they all encompass elements characteristic for this period. At the same time, some people claim that the post-growth concept is still overly focused on ecological issues, without paying due attention to social, economic, class and political aspects (Fotopoulus, 2007; Dengler, Seebacher, 2019).

This evolution was also accompanied by changes in the approach to the role and attitudes of a human in socio-economic and political processes. According to some researchers, this means an evolution from homo-oeconomicus to homo cooperativus - an independent man responsible for his own deeds and needs who, however, faced with limitations of his problem-solving abilities, is willing to deal with other people who not only share the same difficulties, but are also similarly prone to team solving common concerns (Daudi, Sotto, 1986; Stasiak, 2013; Rogall, 2009; Schräder, 2007). In turn, homo oeconomicus can be described as an entity that has a specific economic goal and selects the most effective ways to achieve it based on the acquired knowledge of the available means and circumstances that may ease it. This man is self-interested, works rationally, maximises his own usefulness, has certain preferences and full information (Horodecka, 2014, Sztumski, 2018). However, such a human model responds to the challenges of a very dynamic knowledge-based economy with a network structure only to some extent - an economic man is a selfish rational person, strongly focused on his own needs and having a fixed order of preferences. Furthermore, his rationalism becomes short-sighted in the times that Bauman (2012) defines as a period of interregnum and Popkiewicz (2012) calls the world at the crossroads. Undoubtedly, these are the times of uncertainty and doubt, the times when questions about the organisation of the institution, the future of migrants, the permanence of the planet and the sense of community within diversity are relatively frequent.

While homo oeconomicus has already made a world career as the basic model of a man in the economy, homo cooperativus gradually gains the attention of scientists (anthropologists and economists) who analyse the issue of sustainable development econom- ics. These paths of reshaping the view of the human image in economic and social system, however, are by no means exhaustive. As Horodecka (2014) points out, the assumptions of the homo oeconomicus concept provoked considerable controversy which led to the creation of numerous alternative concepts, such as homo reciprocans, cooperativus, sociologicus, ecologicus/sustinens and animal spirits. Homo reciprocans indicates the essential feature of a man - his strive for fairness, guided by the principle of tit for tat. Homo cooperativus is associated with environmental economics or ecological economics (German: Umweltökonomie) and assumes the coexistence of two elements - self-responsibility and mutual help (symbiosis and cooperation). Another model, homo sustinens, was developed within the realm of sustainable economics. Homo sociologicus is a human model created based on sociology, but largely taken over by the institutional economy. Man is perceived here not only as a being conditioned by other people, but also the one who must comply with their norms, values and expectations (there is a distinction between the necessity, duty and opportunity).

Despite the evolution process described above, sustainable development has a clearly defined key assumption that can be found at every stage of its evolution - the integration of its economic and social dimensions with the environmental one. Moreover, intergenerational justice in access to natural resources also comprises an important issue here. The next part of this article will be devoted to versatile ways of implementing this concept at a city level.

\section{Review of the sustainable urban develop- ment concept}

Not only has sustainable development concept gained a global, national and local dimension (Agenda 21), but especially the urban one (Leipzig Charter on Sustainable European Cities, 2007, the New Urban Agenda 2016). It tends to be perceived as a key urban policy element (Glaeser, 2011; Johnston et al., 2013). According to Rogers (1997), sustainable city meets social, cultural, environmental and political requirements and simultaneously pursues economic and physical goals, ensures equal access to all the services without undermining the resources of both other cities and the region itself. According to Robertson, sustainable city may also be perceived as a holistic system in which social, economic, environmental, and institutional aspects of development are harmoniously integrated (2012).

Sustainable urban development is a response to such challenges as high environmental degradation, greenhouse gas emissions and resource exploitation, high energy consumption as well as concentration of poverty in urbanised areas. At the same time, it sets the course for the future urban development planning. According to the Leipzig Charter (2007), the 
pursuit of sustainable urban development should focus on the development of a resource-efficient and low-emission economy, an integrated approach to development planning and territorial organisation of activities, prevention and minimising of social problems, limitation of uncontrolled urban sprawl, high level of environmental protection and quality of the environment in and around cities, building the ability to adapt to climate change, establishing cooperation in the implementation of common goals within sustainable development. Riffat, Powell, Aydin (2016) elaborate more on the need to develop the new sustainable development model which includes better incentives to save energy, reduce consumption and protect the environment while increasing the level of citizens' well-being. The shared vision of the future European city is also formulated by the European Commission, Directorate General for Regional and Urban Policy (2011). The city of the future is defined here as a place of an advanced social progress with a high level of social cohesion, socially sustainable housing, social and health services and public education. It also comprises a space for the democratic process, cultural dialogue and diversity, a place of natural, ecological and environmental revitalisation, and finally a powerful engine for economic growth. The environmental, spatial, social and economic aspects of sustainable urban development are being developed in numerous detailed concepts. However, the assessment of the complexity of their assumptions indicates that not all of them are equally sensitive to the social, economic and environmental perspectives of development, but rather focus on key aspects of the desired city from narrowly defined perspectives (Khan, Zaman, 2018). For example, compact city focuses mainly on the urban structure of the city (Breheny, 1995; Pearsall, 2017; Neuman, 2005; Crommelin et al., 2017; Salingaros, 2006), eco-city - on the environment (Joss, 2011; Jabareen, 2006; Girardet, 2008; Cugurullo, 2016), smart city - on technology (Caragliu et al., 2011; Kitchin, 2014; Kummitha and Crutzen, 2017). Despite clearly defined priorities, these three urban development models share many aspects and to a large extent fit into the sustainable development idea. We would like to point out again that the literature review facilitates the description of other development models, much more specialised when it comes to target groups or the conduct of business rules. This includes agefriendly city (WHO, 2007) or sharing city. The former focuses on the high quality of life of the elderly whereas the assumptions of the latter refer to the methods of organising the economic and social activity of city users. Both these concepts, however, are directed towards selected and narrowly perceived urban issues - for this reason they will not be included in our in-depth analysis.

\subsection{Eco city and circular city}

At the end of the first decade of the 2000s, the phenomena of sustainable consumption and production, green growth, low-emission economy and resource efficiency were gradually combined and linked to the new economic model known as the green economy. Eco-city and circular economy concepts are deeply embedded in this model. The green (eco-) city assumes the transfer of solutions functioning in nature to urban systems. The key feature of this concept is to exploit as fully as possible renewable sources (solar, wind and water energy) and fresh water as well as economical consumption of these resources (Węcławowicz-Bilska, 2012). As a result of the employment of appropriate technologies, including recycling and organisational solutions, it is possible in a green city to significantly reduce the use of non-renewable resources and energy, as well as pollution emitted to the natural environment. Here, also the city transportation system should be based on public communication with vehicles powered by renewable energy sources as well as bicycles and electric cars. Technology is crucial in this concept; therefore, it integrates well with urban intelligence idea. The sustainable development concept is also connected with the idea of a circular economy, CE, (otherwise known as circularity, closed loop or cradle to cradle C2C). CE began to develop in the 1970s as an alternative economic model that challenged the traditional linear industrial economy. Linear economy is based on a linear process which is optimised for high throughput and low production costs and which assumes high availability of raw materials at a relatively low cost. A typical process consists of a series of steps - resource extraction, production, consumption and utilisation of products at the end of their life cycle. This scheme is sometimes referred to as a take-make-consume-dispose model (Taranic, 2016). In turn, the circular economy system allows for the extended product lifetime and the complete elimination of waste, and thus is saves raw materials (COM 2015). It consists in closing the life cycle of products in which the product does not end up in the bin and landfill after its use, but is reused through recovery and recycling (Zarębska, 2017). The circular economy system is aimed at preventing depletion of resources, closing energy and material loops and facilitating sustainable development at the micro level (enterprises and consumers), meso (economic factors integrated in symbiosis) and macro (city, regions and governments) (Prieto-Sandoval, Jaca, Ormazabal, 2018; Marin, De Meulder, 2018). For this reason, it is more often employed in urban and regional development strategies and becomes the subject of urban innovation. This is accompanied by the transition from urban linear to circular system.

\subsection{Smart city}

The development of the economy and the digital society leads to the computerisation of urban services 


\section{Smart Economy}

innovativeness, entrepreneurship business support institutions supporting innovative companies high technology industries image of the city productivity flexibility of the economy and labour market international embeddedness ability to transform

\section{Smart People}

(Social and Human Capital)

education

lifelong learning

pluralism

flexibility

creativity

cosmopolitanism

participation in public life

\section{Smart Governance \\ (Smart Participation)}

participation in public life high quality public and social services

transparent governance public policies and strategies that respond to the challenges of the environment use of research knowledge

\begin{tabular}{l} 
Data on social net- \\
works \\
$\begin{array}{l}\text { Data on infrastruc- } \\
\text { ture/urban resources }\end{array}$ \\
Data on the environ- \\
ment \\
Data on the demand \\
for public services \\
\hline $\begin{array}{l}\text { Smart Mobility } \\
\text { (Transport and ICT) } \\
\text { local accessibility } \\
\text { (inter-)national accessibility } \\
\text { availability of ict infrastructure } \\
\text { sustainable and safe transport } \\
\text { system }\end{array}$ \\
\hline
\end{tabular}

\section{Smart Environment} (Natural Resources)

reducing environmental pollution

environmental protection natural resource management sustainable management of environmental resources by means of renewable energy energy-saving technologies education

Figure 1. Elements of smart city, source: own elaboration based on Fazlagić, 2015

and the control of urban subsystems by means of advanced technologies. The smart city concept encompasses these phenomena and combines ecological, environmental and social elements with ubiquitous information and communication technology. As Stawasz and Sikora-Fernandez (2015) note, intelligent city should be understood as a multi-aspect concept of urban development based on an intelligent approach to solving various problems and using the possibilities offered by IT systems. Its implementation should lead to the effective use of available resources, especially technical and technological, improvement of the quality of life in the city and ensuring its sustainable development (Khansari, Mostashari, Mansouri, 2013). Traditionally, key smart sectors include public transport, health care and waste management. Furthermore, smart city instruments also encompass communication tools used to examine residents' expectations and needs as well as organise and trigger social activity. The smart city model promoted by Austrian scientists from the Vienna University of Technology (Giffinger, 2007) distinguishes six fields of urban intelligence activity on the basis of the active participation of conscious, independent and decisive citizens (Figure 1): Smart Economy, Smart People, Smart Governance, Smart Living, Smart Mobility, Smart Environment.

The emphasised areas are combined by modern information and communication technologies that ensure the efficiency of urban management, as well as 
the efficiency of the urban economy that provides services to urban residents and meets their needs. The increase in efficiency results from the urban resources (financial, time, space, environment, energy) saved thanks to modern technologies. A smart city is therefore a city with educated citizens, city that employs new channels of communication between the local administration and the inhabitants (Lombardi, Giordano, Farouh, Wael, 2012). The idea behind the concept is to strive to increase innovation and flexibility of the urban economy and to respond quickly to local and global challenges. A city can be described as intelligent when it invests in human and social capital and communication infrastructure in order to actively promote sustainable development and civic participation (Ferrara, 2015).

The smart city development is based on the Internet of Things, i.e. all intelligent devices connected to the Internet, that can react to the changes of the environment and process information, as well as send it to other objects or users (Nowakowski, 2015). The potential of its usage in cities is theoretically large. By obtaining information in real time through sensor/device systems and integration of the generated data, the management of urban processes may be improved (parking, waste management, street lighting, monitoring the environment and roads quality, etc.). On the other hand, these devices generate additional energy consumption as well as e-waste and hazardous emissions.

Distinguished by Cohen, the latest generation of smart cities (Smart City 3.0, also referred to as $\mathrm{Hu}$ man Smart Cities or Sharing Smart Cities) encompasses cities that are co-created by ICT residents (Cohen, 2018). The role of local authorities is to create space and opportunities to use the diverse citizens' potential and build the intelligence of the city. What needs to be stressed here is that focusing on technology and hard infrastructure only is one of the main mistakes made while planning the construction of a smart city. The essence of urban intelligence should lie in the use of intelligence and knowledge of residents who - often equipped with simple tools - are able to independently meet their needs in a more efficient way than the local administration (Bendyk, Bonikowska, Rabiej, Romański, 2013). Thanks to this, infrastructural investments may be supported by social capital, i.e. the energy of cooperation between active and committed citizens.

\subsection{Compact city and urban revitalisation}

Social, environmental and economic issues perceived from the sustainable development perspective can be found within concepts of urban design. Compact city, known also as city of short distances, should be pointed out here in particular. It focuses on the concentration of strategic functions and compact development of the strict city centre. Though there is no single fixed definition of a compact city, the main assumptions of this concept are clearly defined, e.g. in the OECD report on Poland which states that the compact city is spatial urban form characterised by 'compactness'. Its key characteristics are: dense and proximate development patterns, urban areas linked by public transport systems and accessibility to local services and jobs (OECD, 2012). Economic arguments for such an urban approach are quite understandable, it is mainly about lower infrastructure and transport costs. Although, according to some authors, excessive city compactness may lead to a decrease in the quality of life (Neuman, 2005), others point to a clearly positive relationship between the city's compactness and the satisfaction with life in it. Mouratidis' research (2017) shows that residents of compact cities seem to be much more satisfied with their neighbourhood compared to those living in diffused (often chaotically) suburban areas. The higher the level of compact features in the city, the greater the satisfaction from the neighbourhood. This relationship occurs since densely populated areas offer easy access to amenities and public transport.

The need to conduct actions to increase the attractiveness of city centres often results from the desire to stop the uncontrolled suburbanisation. It is also motivated by the degree of degradation of the urban fabric and the loss of existing socio-economic functions in these areas. Thus, the balanced compact city comprises a model of urban development which assumes that the dispersion of buildings will cease, revitalisation and development of degraded areas will be supported, car traffic will be limited and public transport, cycling and walking will gain the priority. Revitalisation is perceived here as a method of effective management and use of the space of city centres, including measures to improve the quality of life of their residents and the social inclusion of marginalised groups. Considered within the paradigmatic dimension, it is embedded in the mainstream of sustainable development. Thus, it is a comprehensive process which focuses on solving important city problems, generating benefits for both its current and future population (Peng et al., 2015, Gedik, Yildiz, 2016). Importantly, improvement of the life quality of the entire local community, including residents of the degraded areas and disadvantaged groups in particular, is considered critical here (Alpopi, Manole 2013; Woodcraft, Hackett, Caistor-Arendar, 2011). Revitalisation is a response to a multidimensional and deep crisis of a specific urban area. It is therefore a long-term process of repairing the economic, physical, social and environmental properties of an area that lost its original functions and experiences a collapse. Its fundamental principles include: the need to establish clear and measurable revitalisation objectives that are consistent with sustainable development principles, appropriate diagnosis of local conditions, effective use of endogenous natural, economic and human resources, stakeholders' partnership and cooperation which leads to the improvement of the physical condition of buildings, social 
structure, economic base and environmental conditions (Roberts, Sykes, 2000; Darchen, Ladouceurb, 2013). The universal design (the philosophy of product and environment design in such a way that it is accessible to all the people, to the extent possible) and social economy (a tool for socio-economic development, complementary to the public and private sector, enabling the activation and integration of people and groups vulnerable to social exclusion) are vital for the effectiveness of revitalisation methods that lead to inclusion.

\section{Discussion on contemporary urban develop- ment concepts}

All the above described concepts fall under the sustainable development trend. Therefore, the developmental challenges of cities should be comprehensively perceived, balancing environmental, social and economic phenomena. Meanwhile, the discussed concepts sometimes remain conflicted. As a result, they gain as many supporters as critics. The already described urban concept of a compact city may serve as an example here. The advantages of this approach encompass lower costs of housing unit construction and heating which additionally translates into energy savings (Mierzejewska, 2015), reduction of construction, maintenance and lighting costs per one inhabitant, but also other infrastructure systems (Mierzejewska, 2006, Jenks and Jones, 2010). However, loss of open urban public spaces (social threat) and valuable natural spaces (ecological threat) are mentioned among the potential disadvantages of such an approach to spatial development of cities (Jenks and Jones, 2010). Thus, this concept may pose a threat to the green city development model and its social cohesion and durability - what has been confirmed by the research results (Cao, 2016; Okulicz-Kozaryn, 2015). Neuman (2005) even introduces the compact city paradox which links the areas characterised by lower density with higher living levels while higher densities are considered necessary to achieve sustainable development goals. Though these ideas were proven invalid by Mouratidis' research (2017), his studies were limited and concerned only Oslo and its suburban area. Overall, literature considers compact city as balanced and effective as well as potentially threatening the balance and cohesion, or even assuming the strive to achieve them as the core values of urban policy through the renewal of degraded areas.

Eco city and smart city have also been criticised. The subject of criticism here is the inconsistency of the assumptions with their implications (Cugurullo, 2017) which stems from their utopian character. In reality, intelligent and ecological urban initiatives are not homogeneous experiments, but rather disconnected projects consisting of many counterproductive sub-projects. For this reason, these initiatives do not realise their potential for sustainable development and create spaces that are conducive to social injustice and the loss of biodiversity. Rapoport (2014) prepared a review of negative aspects of the implementation of eco city projects. She quoted the authors who point out that eco city undertakings are primarily business, commercial and marketing projects with economic issues ahead of the environmental ones (Cugurullo, 2013; Datta, 2012; de Jong et al.., 2013; Shwayri, 2013, Shen and Wu, 2012; Wu, 2012; Evans and Karvonen, 2011; Myllylä and Kuvaja, 2005). In turn, Chang and Sheppard (2013) connect the eco-city with the green capitalism idea, in which environmental changes are supported by capital investments, individual choices and innovations in the field of entrepreneurship. They believe that basing the promotion of the city and local economic growth on nature and ecology may lead to their degradation. Another criticised issue identified by Rapoport refers to the lack of universalism of eco city solutions. These projects often use advanced, expensive technological solutions that are impractical or unavailable to many cities (Cheng and $\mathrm{Hu}$, 2010; Lye and Chen, 2010; May, 2008; Myllylä and Kuvaja, 2005). Implementation of eco innovations may therefore contribute to the growth of inequalities and exclusion from the access to the generated effects.

In the concepts of sustainable cities presented above, there are both common assumptions and contradictions, which in our opinion leads to the need for a new idea. The summary of our work will be therefore devoted to recommendations related to defining the conceptual framework for a sustainable development model of a modern and future inclusive city where solidarity, social cohesion and quality of life are the most essential components.

\section{Conclusions}

To determine the key values and principles of sustainable development of modern cities, we note that four main goals are manifested, though to a diversified degree, in all the earlier discussed concepts:

- ecology and economical management of natural resources,

- $\quad$ social and spatial cohesion,

- local economy and its development,

- urban intelligence.

The methods of their implementation seem clear and include: revitalisation, digitisation, green economy, shared economy and circular economy. Institutional factors such as partnership, participation, cooperation, empowerment and efficient public management comprise the cross-sectional determinants of the implementation of sustainable development goals. Significant determinants for shaping the contemporary model of urban development include also modern megatrends, such as globalisation and mi- 


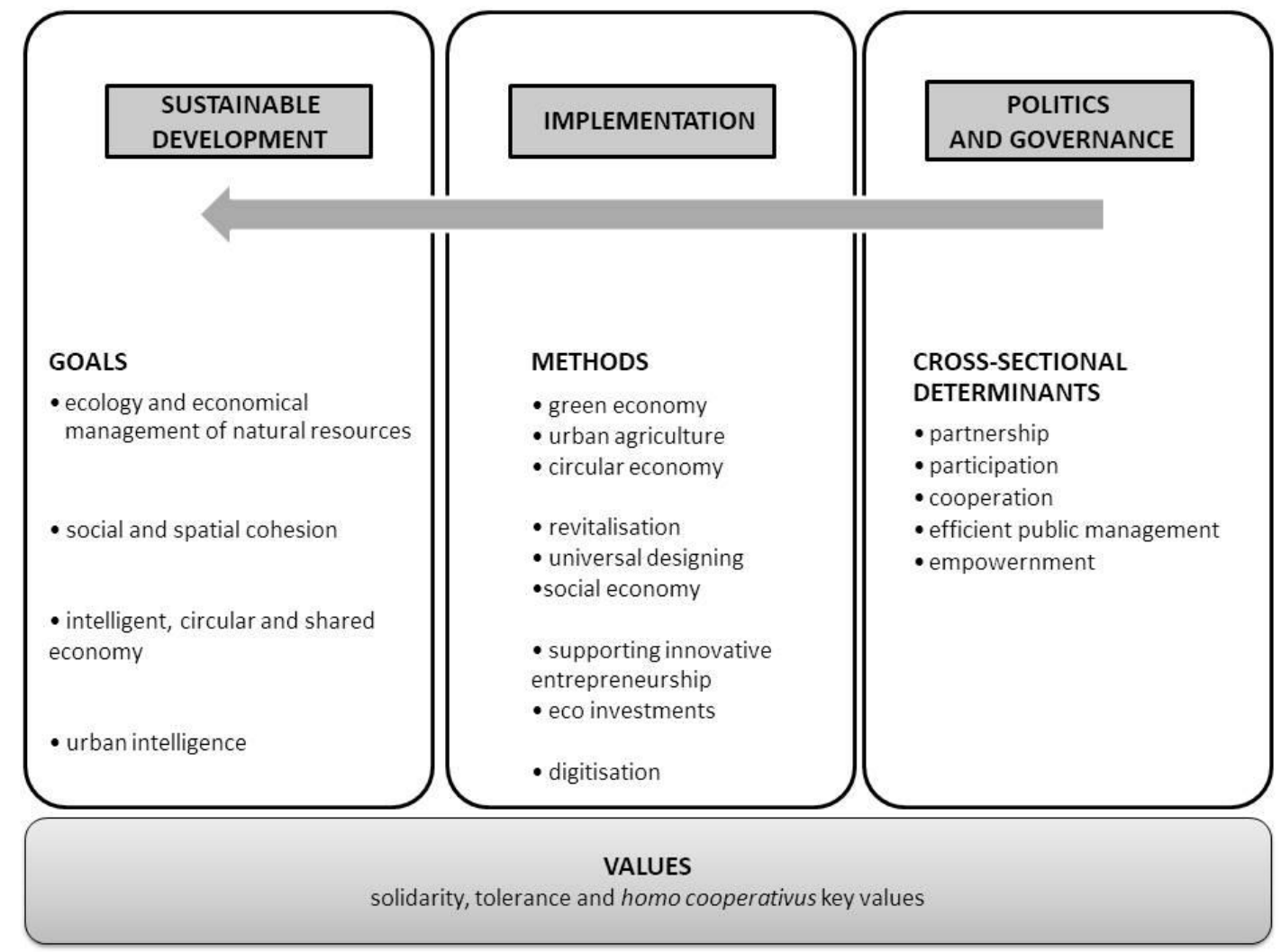

Figure 2. Theoretical assumptions of the sustainable urban development model, source: own elaboration

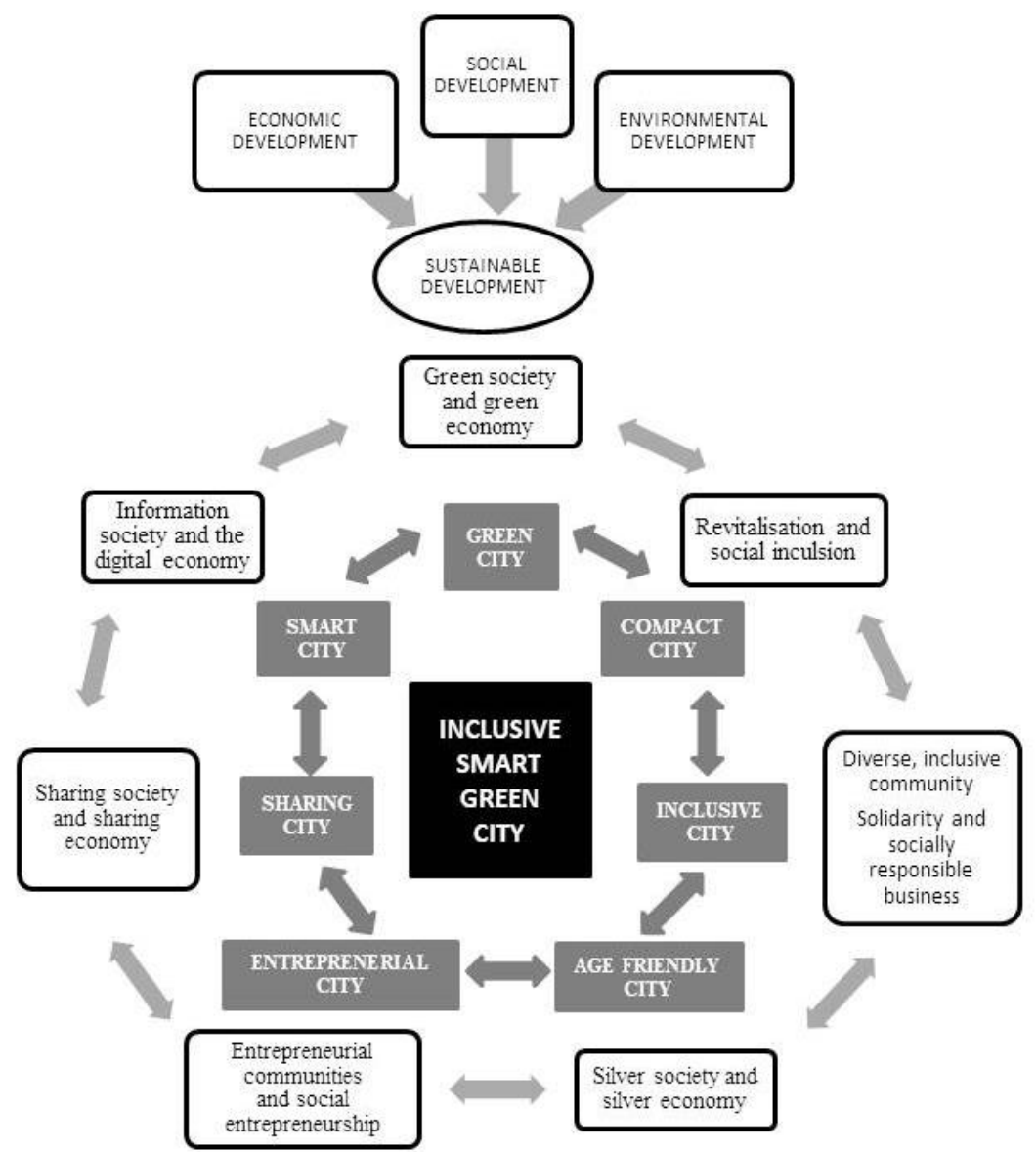

Figure 3. Integration of the urban development concept - an inclusive sustainable development city model, source: own elaboration 
gration movements, which result in local communities' diversity, as well as the challenge of an aging society, which among others influences on the development of services and products for older consumers.

Referring to the above assumptions, we suggest a conceptual model of an ideal city based on the mechanisms and potential of green, digital, shared and socially responsible economy as well as green and information society and inclusive communities - it is called an inclusive sustainable city model.

In our view, the development towards an inclusive sustainable city means integrated and solidary activities of many stakeholders, co-led by the local community - respecting its internal diversity, aimed at improving the quality of life and management conditions in the city, striving to equalise opportunities to access the city's resources for versatile present and future groups of residents and creating a wide range of local community development opportunities, using intelligent, pro-ecological and shared solutions. The model of an inclusive sustainable city summarises the assumptions of sustainable development concepts discussed earlier in the article with regards to the new conditions and sustainable urbanisation. Activities in the area of social inclusion of excluded or marginalised people, together with the elderly and minorities, whose share in population of European cities is systematically increasing, should play a special role in it. Furthermore, inclusion aims to improve the quality of life in the city of its all social groups; reduce the factors that limit the use of a) public services, b) environmental resources, c) smart solutions, d) the local economy system and adjust solutions to the needs and opportunities of various city users, including those who are disadvantaged for some reasons. In our opinion, social inclusion is a sine qua non condition for the sustainable development of cities. The lack of inclusion, equality and social justice in this development model may cause: gentrification as a failure of revitalisation, deepened digital exclusion and exclusion from modern urban services of the elderly and the poor (a negative effect of smart city) and further energy impoverishment of households through the use of green but still expensive sources of energy. The involvement of many stakeholders in the development of the city, to enable the integration of their material and non-material resources in a joint and solidary vision of development comprise the underlying condition of success within this model.

The urban model of an inclusive sustainable city suggested here is simultaneously a summary and an attempt to integrate numerous detailed concepts. It focuses on solidarity and social inclusion which reflect both the point of equilibrium and the basis for the sustainability of development processes. Our future research efforts will focus on the empirical verification whether it is possible to implement this model in Polish municipalities. For this reason, we carry out research on local government management and verify the opinions of the authorities about the possibility of transition towards inclusive sustainable development with regards to new urban challenges.

\section{References}

1. AGYEMAN J., MCLAREN D., SCHAEFERBORREGO A., 2013, Sharing Cities, Briefing for Friends of the Earth, http://www.foe.co.uk/sites/default/files/downloads/agyeman_sharing_cities.pdf.

2. ALPOPI C., MANOLE C., 2013, Integrated Urban Regeneration - Solution for Cities Revitalize, in: Procedia Economics and Finance, 6, p. 178-185.

3. BAUMAN Z., 2012, Times of interregnum, in: Ethics \& Global Politics 5(1), p. 49-56.

4. BAUMAN Z., BAUMAN I., KOCIATKIEWICZ J., KOSTERA M., 2017, Zarządzanie w plynnej nowoczesności, Bęc Zmiana, Warsaw.

5. BENDYK E., BONIKOWSKA M., RABIEJ P., ROMAŃSKI W., 2013, Energia nowego miasta, Przyszłość miast. Miasta przyszłości. Strategie i wyzwania innowacyjne, spoleczne $i$ technologiczne, Raport ThinkTank, Warsaw.

6. BORNSTEIN D., 2010, Jak zmieniać świat. Przedsiębiorcy społeczni - wizjonerzy naszych czasów, AnWero, Gdańsk.

7. BORYS T., CZAJA S., 2009, Badania nad zrównoważonym rozwojem w polskich ośrodkach naukowych, in: Od koncepcji ekorozwoju do ekonomii zrównoważonego rozwoju, ed. Kiełczewski D., Wydawnictwo Wyższej Szkoły Ekonomicznej w Białymstoku, Białystok, p. 51-58.

8. BREHENY M., 1995, The compact city and transport energy consumption, in: Transactions of the Institute of British Geographers, p. 81-101.

9. BÜCHSA M., KOCH M., 2019, Challenges for the degrowth transition: The debate about wellbeing, in: Futures 105, p.155-165.

10. BUNKER R., CROMMELIN L., RANDOLPH B., TROY L., EASTHOPE H., PINNEGAR S., 2017, As compact city planning rolls on, a look back: lessons from Sydney and Perth, in: Australian Planner, 54(2), p. 115-125.

11. CAO X., 2016, How does neighborhood design affect life satisfaction? Evidence from Twin Cities, in: Travel Behaviour and Society, 5, p. 68-76.

12. CARAGLIU A, DEL BO C., NIJKAMP P., 2011, Smart cities in Europe, in: Journal of Urban Technology, 18(2), p. 65-82.

13. CHANG I.C., SHEPPARD E., 2013, China's eco cities as variegated urban sustainability: Dongtan eco city and Chongming eco island, in: Journal of Urban Technology 20(1), p. 57-75.

14. Closing the loop - An EU action plan for the Circular Economy, COM (2015) 614.

15. COHEN B., The 3 Generations of Smart Cities, https://www.fastcompany.com/3047795/the-3-generations-of-smart-cities (28.04.2018).

16. CUGURULLO F., 2013, How to build a sandcastle: an analysis of the genesis and development of Masdar city. in: Journal of Urban Technology, 20(1), p. 2337.

17. CUGURULLO F., 2016, Urban eco-modernisation and the policy context of new eco-city projects: 
Where Masdar City fails and why, in: Urban Studies, 53(11), p. 2417-2433.

18. CUGURULLO F., 2017, Exposing smart cities and eco-cities: Frankenstein urbanism and the sustainability challenges of the experimental city, in: Environment and Planning, A0(0), p. 1-20.

19. DARCHEN S., LADOUCEUR E., 2013, Social sustainability in urban regeneration practice: a case study of the Fortitude Valley Renewal Plan in Brisbane, in: Australian Planner, 50, p. 340-350.

20. DATTA A., 2012, India's ecocity? Environment, urbanisation, and mobility in the making of Lavasa, in: Environment and Planning C: Government and Policy, 30(6), p. 982-996.

21. DAUDI, P., SOTTO, R., 1986, European cooperations in transition - the metamorphosis of homo cooperativus, in: Scandinavian Journal of Management Studies, 3(1), p. 65-85.

22. DE JONG, M., YU, C., CHEN, X., WANG, D., WEIJNEN, M., 2013, Developing robust organizational frameworks for Sino-foreign eco-cities: comparing Sino-Dutch Shenzhen low carbon city with other initiatives, in: Journal of Cleaner Production, 57, p. 209-220.

23. DENGLER, C., SEEBACHER, L. M., 2019, What About the Global South? Towards a Feminist Decolonial Degrowth Approach, in: Ecological Economics, 157, p. 246-252.

24. DESLATTE A, STOKAN E., 2017, Hierarchies of Need in Sustainable Development: A Resource Dependence Approach for Local Governance, in: Urban Affairs Review, p. 1-28.

25. EVANS J., KARVONEN A., 2011, Living laboratories for sustainability: exploring the politics and epistemology of urban transitions, in: Cities and low carbon transitions, ed. Bulkeley H., Castan-Broto V., Hodson M., Marvin, S., Routledge Studies in Human Geography, Routledge, London, p. 126-141.

26. EUROPEAN COMMISSION, 2011, Directorate for Regional Policy, Cities of the future, Challenges, visions, perspectives, http://ec.europa.eu/regional_ policy/conferences/citiesoftomorrow/index_en.cfm

27. FAZLAGIĆ J., 2015, Smart City+. Jak wykorzystać koncepcję Smart Cities oraz pokrewną Smart Specialization do wsparcia rozwoju mniejszych miast w Polsce?, in: Ekspertyzy NIST, 1(1), p. 5.

28. FERRARA R., 2015, The Smart City and the Green Economy in Europe: A Critical Approach, in: Energies, 8, p. 4724-4734.

29. FOTOPOULOS T., 2007, Is degrowth compatible with a market economy?, in: The International Journal of Inclusive Democracy, 3(1), p.1-16.

30. GEDIK G. S., YILDIZ D., 2016, Assessing the role of users in sustainable revitalization of historic urban quarters: The case of Bursa-Khans District, in: $A / Z$ ITU Journal of the Faculty of Architecture, 13, p. 195-208.

31. GIFFINGER R., FERTNER C., KRAMAR H., KALASEK R., PICHLER-MILANOVIÜ N., MEIJERS E., 2007, Smart Cities: Ranking of European Medium-Sized Cities, Centre of Regional Science (SRF), Vienna University of Technology, Vienna.

32. GIRARDET H., 2008, Cities, people, planet: urban development and climate change, John Wiley, Chichester.

33. GLAESER E. L., 2011, Triumph of the City: How Our Greatest Invention Makes Us Richer, Smarter,
Greener, Healthier, and Happier, Penguin Press, New York.

34. HARMAALA M.M., 2015, The Sharing City as a Platform for a More Sustainable City Environment?, in: Int. J. Environment and Health, 7(4), p. 309-328.

35. HEIKKURINEN P., LOZANOSKA J., TOSI P., 2019, Activities of degrowth and political change, in: Journal of Cleaner Production, 211, p. 555-556.

36. HORODECKA A., 2014 'Homo oeconomicus' jako podstawa ekonomii - krytyka i alternatywy, in: Prace Naukowe Uniwersytetu Ekonomicznego we Wrockawiu, Ekonomia, eds Sokołowski J., Rękas M., Węgrzyn G., 347, p. 166-183.

37. JABAREEN Y. R., 2006, Sustainable urban forms: their typologies, models, and concepts, in: Journal of Planning Education and Research, 26, p. 38-52.

38. JENKS M., JONES C. (eds), 2010, Dimensions of the Sustainable City, Springer, London.

39. JOHNSTON S., NICHOLAS S., PARZEN J., 2013, The Guide to Greening Cities, Island Press, Washington, DC.

40. JOSS S., 2011, Eco-cities: the mainstreaming of urban sustainability; key characteristics and driving factors, in: International Journal of Sustainable Development and Planning, 6(3), p. 268-285.

41. KAHN S., ZAMAN A.U., 2018, Future cities: Conceptualizing the future based on a critical examination of existing notions of cities, in: Cities, 72, p. 217 225.

42. KARTA Lipska na rzecz zrównoważonego rozwoju miast europejskich, 2007.

43. KHANSARI N., MOSTASHARI A., MANSOURI M., 2013, Impacting Sustainable Behaviour and Planning in Smart City, International Journal of Sustainable Land Use and Urban Planning, 1(2), p. 4661.

44. KITCHIN R., 2014, The real-time city? Big data and smart urbanism, in: GeoJournal, 79(1), p. 1-14.

45. KUMMITHA R.K.R., CRUTZEN N., 2017, How do we understand smart cities? An evolutionary perspective, in: Cities, 67, p. 43-52.

46. LIN K.W., SHIH C.M., 2018, The comparative analysis of neighborhood sustainability assessment tool, in: Environment and Planning B: Urban Analytics and City Science, 45(1), p. 90-105.

47. LOMBARDI P., GIORDANO S., FAROUH H., WAEL Y., 2012, Modelling the smart city performance, in: Innovation: The European Journal of Social Science Research, 25(2), p. 137-149.

48. LYE L. F., CHEN G., 2010, Some thoughts on the development of eco-cities in Asia. in:. Towards a liveable and sustainable urban environment: eco-cities in East Asia, eds Lye L. F., Chen G., World Scientific Publishing, Singapore, p. 57-90.

49. MĄCZYŃSKA E., 2011, Stenogram z Forum Myśli Strategicznej pt. Ekonomia w warunkach gospodarki nietrwałości - April 5.

50. MARIN J., DE MEULDER B., 2018, Interpreting Circularity. Circular City Representations Concealing Transition Drivers, in: Sustainability, MDPI, Open Access Journal, 10(5), 1-24.

51. MAY S., 2008, Ecological citizenship and a plan for sustainable development - lessons from Huangbaiyu, in: City: Analysis of Urban Trends, Culture, Theory, Policy, Action, 12(2), p. 237-244.

52. MIERZEJEWSKA L., 2006, Rola planowania przestrzennego w rozwoju zrównoważonym miast, in: 
Polityka zrównoważonego rozwoju oraz instrumenty zarządzania miastem, eds Słodczyk J., Rajchel D., Uniwersytet Opolski, Opole.

53. MIERZEJEWSKA L., 2015, Miasto zwarte, rozproszone, zrównoważone, in: Studia Miejskie, 19, p. 922.

54. MOURATIDIS K., 2017, Is compact city livable? The impact of compact versus sprawled neighbourhoods on neighbourhood satisfaction, in: Urban Studies, 55(11), p. 2408-2430.

55. MYLLYLÄ S., KUVAJA K., 2005, Societal premises for sustainable development in large southern cities, in: Global Environmental Change Part A, 15(3), p. 224-237.

56. NEUMAN M., 2005, The compact city fallacy, in: Journal of Planning Education and Research, 25(1), p. 11-26.

57. NEWMAN P., BEATLEY T., BOYER H., 2009, Resilient cities: responding to peak oil and climate change, Island Press.

58. NIKOS A. S., 2006, Compact City Replaces Sprawl, in: Crossover: Architecture, Urbanism, Technology, eds Graafland A., Kavanaugh L., 010 Publishers, Rotterdam, Holland, p.100-115.

59. NOWAKOWSKI W., 2015, Bliższa chmura, czyli usługi obliczeniowe we mgle, in: Elektronika - konstrukcje, technologie, zastosowania 5, Instytut Maszyn Matematycznych, Warsaw,

http://www.imm.org.pl/imm/plik/pliki-do-pobraniaelektronika52015_nn358.pdf (16.12.2016).

60. OECD, 2012, Compact City Policies: A Comparative Assessment, OECD Green Growth Studies, OECD Publishing, p. 15.

61. OKULICZ-KOZARYN A, 2015, Happiness and Place: Why Life is Better Outside of the City, Palgrave Macmillan, New York.

62. PAPUZIŃSKI A., 2018, The Enlightenment Assumptions of the Brundtland Report, in: Problemy Ekorozwoj/uProblems Of Sustainable Development, 13(1), p. 7-14.

63. PEARSALL H., 2017, Staying cool in the compact city: Vacant land and urban heating in Philadelphia, in: Pennsylvania Applied Geography, 79, p. 84-92.

64. PENG Y., LAI Y., LI X., ZHANG X., 2015, An alternative model for measuring the sustainability of urban regeneration: the way forward, in: Journal of Cleaner Production, 109, p.76-83.

65. PERKINS P.E., 2019, Climate Justice, Commons, ad Degrowth, in: Ecological Economics Volume, 160, p. 183-190.

66. PIKETTY T., 2015, Kapitat w XXI wieku, Wydawnictwo Krytyki Politycznej, Warsaw.

67. POPKIEWICZ M., 2012, Świat na rozdrożu. Wyd. 2., Sonia Draga, Katowice.

68. PORTNEY K. E., 2013, Taking Sustainable Cities Seriously: Economic Development, the Environment, and Quality of Life in American Cities, MIT Press, Cambridge.

69. PRIETO-SANDOVAL V., JACA C., ORMAZABAL M., 2018, Towards a consensus on the circular economy, in: Journal of Cleaner Production, 179, p. 605-615.

70. RAPOPORT E., 2014, Utopian Visions and Real Estate Dreams: The Eco-city Past, Present and Future, in: Geography Compass, 8(2), p. 137-149.
71. RIFFAT S., POWELL R., AYDIN D., 2016, Future cities and environmental sustainability, in: Future Cities and Environment, 2(1), p.1-23.

72. ROBERTS P.W., SYKES H., 2000, Urban Regeneration, A Handbook, SAGE.

73. ROBERTSON M., 2012, Sustainable cities. Local solutions in the Global South, International Development Research Centre, UK, p.4-5.

74. ROGALL H., 2009, Vom Homo oeconomicus zum Homo cooperativus: zur Notwendigkeit einer Transformation der traditionellen Ökonomie, in: Zeitschrift für Bürgerrechte und Gesellschaftspolitik, 48(1), p. 93-105.

75. ROGERS R., 1997, Cities for a small planet, Faber and Faber Limited, London, p. 26.

76. RYDZEWSKI P., 2019, Social Dimensions of Sustainable Development in International Public Opinion, in: Problemy Ekorozwoju/ Problems of Sustainable Development, 14(1), p. 53-62.

77. SASSEN S., 2005, The Global City: introducing a Concept, in: Brown Journal of World Affair, 11(2), p. 27-43.

78. SCHRÄDER O., 2007, Wohin wollen wir gehen? Homo oeconomicus und Homo cooperativus-tragfähige Konzepte für die Zukunft?, AG-SPAK-Bücher, Neu-Ulm.

79. SHEN J., WU F., 2012, Restless urban landscapes in China: a case study of three projects in Shanghai, in: Journal of Urban Affairs, 34 (3), p. 255-277.

80. SHWAYRI S. T., 2013, A model Korean ubiquitous eco-city? The politics of making Songdo, in: Journal of Urban Technology, 20(1), p. 39-55.

81. SMĘTKOWSKI, PŁOSZAJ 2016, Porównanie metropolitalnego i historycznego wymiaru zróżnicowania polskiej przestrzeni, in: Polska gmina 2015, ed. Gorzelak G., Wydawnictwo Naukowe Scholar, Warsaw, p. 164-183.

82. SOKOŁOWICZ M., 2017, Miejskie dobra wspólne (commons) z perspektywy ekonomii miejskiej, in: Studia Regionalne i Lokalne, 4(70), p. 23-40.

83. STASIAK M., 2013, Towards community, the ethos of homo cooperativus, in: Humanum, 11(2), p.217228.

84. STAWASZ D., SIKORA-FERNANDEZ D., 2015, Dobre praktyki inteligentnego zarządzania w polskich miastach, in: Studia Miejskie, vol. 19, p. 35-46.

85. STIGLITZ J.E., 2015, Cena nierówności. Wjaki sposób dzisiejsze podziały społeczne zagrażaja naszej przyszłości?, Wydawnictwo Krytyki Politycznej, Warsaw.

86. SZTUMSKI W., 2018, Can Sustainable Human Manage to Prevent Imbalances in the Natural and Social Environment?, in: Problemy Ekorozwoju/ Problems of Sustainable Development, 13(2), p. 45-55.

87. TARANIC I., BEHRENS A., TOPI C., 2016, Understanding the Circular Economy in Europe, from Resource Efficiency to Sharing Platforms: The CEPS Framework, in: CEPS Special Report No. 143, July, p. 1.

88. THERBORN G., 2013, Nierówność, która zabija. Jak globalny wzrost nierówności niszczy życie milionów $i$ jak z tym walczyć, Wydawnictwo Naukowe PWN SA, Warsaw.

89. UNCED (United Nations Conference on Environment and Development), 1992, Agenda 21, New York, http://sustainabledevelopment.un.org/content/ documents/Agenda21.pdf. 
90. VANDEVENTER J. S., CATTANEO C., ZOGRAFOS C., 2019, A Degrowth Transition: Pathways for the Degrowth Niche to Replace the Capitalist-Growth Regime, in: Ecological Economics, 156, p. 272-286.

91. WECŁAWOWICZ-BILSKA E., 2012, Miasto przyszłości - tendencje, koncepcje, realizacje, in: Architektura. Czasopismo Techniczne Politechniki Krakowskiej, 1, p. 323-342.

92. WOŁCZEK P., 2014, Ewolucja podejścia do koncepcji zrównoważonego rozwoju na arenie międzynarodowej, in: Prace Naukowe Uniwersytetu Ekonomicznego we Wroctawiu, 338.
93. WOODCRAFT S., HACKETT T., CAISTOR-ARENDAR L., 2011, Design for Social Sustainability. A Framework for Creating Thriving New Communities, The Young Foundation, London.

94. WHO (World Health Organization), 2007, Global age-friendly cities: A guide, http://www.who.int/ageing/publications/Global_age_friendly_cities_Guide_ English.pdf.

95. WU F., 2012, China's eco cities, in: Geoforum 43(2), p. $169-171$

96. ZAREBSKA J., 2017, Gospodarka o obiegu zamkniętym drogą do zrównoważonego rozwoju, in: Systemy wspomagania w inż. produkcji, 6(7), p. 288. 